\title{
Constituent Order in Tenejapa Tzeltal
}

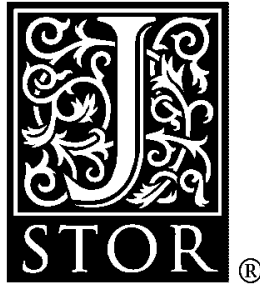

\author{
Stuart Robinson
}

International Journal of American Linguistics, Vol. 68, No. 1. (Jan., 2002), pp. 51-80.

Stable URL:

http://links.jstor.org/sici?sici=0020-7071\%28200201\%2968\%3A1\%3C51\%3ACOITT\%3E2.0.CO\%3B2-2

International Journal of American Linguistics is currently published by The University of Chicago Press.

Your use of the JSTOR archive indicates your acceptance of JSTOR's Terms and Conditions of Use, available at

http://www.jstor.org/about/terms.html. JSTOR's Terms and Conditions of Use provides, in part, that unless you have obtained prior permission, you may not download an entire issue of a journal or multiple copies of articles, and you may use content in the JSTOR archive only for your personal, non-commercial use.

Please contact the publisher regarding any further use of this work. Publisher contact information may be obtained at http://www.jstor.org/journals/ucpress.html.

Each copy of any part of a JSTOR transmission must contain the same copyright notice that appears on the screen or printed page of such transmission.

The JSTOR Archive is a trusted digital repository providing for long-term preservation and access to leading academic journals and scholarly literature from around the world. The Archive is supported by libraries, scholarly societies, publishers, and foundations. It is an initiative of JSTOR, a not-for-profit organization with a mission to help the scholarly community take advantage of advances in technology. For more information regarding JSTOR, please contact support@jstor.org. 


\title{
CONSTITUENT ORDER IN TENEJAPA TZELTAL
}

\author{
STUART Robinson
}

\author{
San Francisco, California
}

1. Introduction. In this paper, I examine constituent order in transitive sentences in the Tenejapa dialect of Tzeltal. ${ }^{1}$ Surprisingly, Tzeltal has received little attention from grammarians, especially in comparison to its closely related sister language, Tzotzil, which has been the subject of a great deal of work (e.g., Aissen 1987 and Haviland 1981). ${ }^{2}$ In fact, many core parts of Tzeltal grammar have never received sustained investigation, even though a few book-length studies of Tzeltal grammar have been published (Robles Uribe 1962 and Kaufman 1971) and the language has been the subject of a good deal of work in linguistic anthropology and language acquisition (e.g., Berlin 1968, Brown 1998, Brown and Levinson 1993; 2000, Hunn 1977, and Stross 1973). To address this gap in the literature, a corpus of narrative texts from the Tenejapa dialect of Tzeltal was systematically tagged for study. ${ }^{3}$ Transitive sentences in the tagged corpus were then subjected to analysis. On the basis of this analysis, I argue that, contrary to previous claims (Smith 1975, Norman and Campbell 1978, and Dayley 1981), the "basic word order"-more accurately, "basic constituent order" (BCO) - of Tenejapa Tzeltal is VOA. ${ }^{4}$ Departures from VOA word order are principled and can be understood in terms of "information packaging" (Foley and Van Valin 1984) or "information structure" (Lambrecht 1994), an area which has been the subject of growing interest due to the recognition of its importance in grammar.

\footnotetext{
${ }^{1}$ The contributions of the following people, who read earlier drafts of this paper and provided comments, are gratefully acknowledged: Sasha Aikhenvald, Judith Aissen, Avery Andrews, Penelope Brown, Lyle Campbell, R. M. W. Dixon, Matthew Dryer, Esteban Guttierez, John Haviland, Eva Lindstrom, and Carl Rubino. Special thanks go to Pedro Hernández Guzmán, the principal Tzeltal native speaker with whom I worked.

${ }^{2}$ Tzeltal belongs to the Cholan-Tzeltalan (or Greater Tzeltalan) branch of the Mayan family (Campbell and Kaufman 1985). It is spoken in both the highlands and the lowlands of Chiapas, Mexico. According to the 2000 census (XI Censo General de Población y Vivenda) conducted by the Mexican government's Instituto de Estadística, Geografía e Informática (INEGI), there are approximately 285,000 speakers of Tzeltal.

${ }^{3}$ Tenejapan Tzeltal is spoken in the municipio of Tenejapa. For information about dialectal variation, see Kaufman (1971:1-2) or Campbell (1987).

${ }^{4}$ Although many authors use the term "basic word order," it is somewhat misleading, since it suggests that what is at issue is the order of words rather than the order of constituents (which may consist of multiple words).
}

[IJAL, vol. 68, no. 1 , January 2002 , pp. 51-80] 
In 2, I examine the concept of "basic word order" and critically evaluate previous claims concerning Tenejapa Tzeltal's BCO. In 3, the corpus tagged for analysis is described and patterns of constituent order are examined for transitive clauses with one or two lexical arguments. The findings of this analysis are reported in 4 . On the basis of these findings, I argue that the BCO of Tenejapa Tzeltal is VOA. In 5, departures from this order are explained in terms of "information structure," which provides additional evidence in favor of VOA as the language's BCO. Finally, I discuss the implications of the findings in 6 and provide a summary in 7.

2. Basic constituent order. In this section, I consider the concept of BCO. The general concept of BCO is explained in 2.1, while previous claims about Tenejapa Tzeltal's BCO are critically examined in $\mathbf{2 . 2}$.

2.1. The concept of BCO. The concept of $\mathrm{BCO}$ is deeply entrenched in linguistic theory and has played a part in a good deal of typological thinking (the locus classicus being Greenberg 1966). Although some authors have called into question the appropriateness of the concept for some languages (e.g., Brody 1984 and Mithun 1992), many linguists continue to utilize the idea in language description. In her overview of constituent ordering in Mayan, England (1991:447-51) discusses a number of criteria for the determination of which sentences count toward the $\mathrm{BCO}$ of a language:

1. The sentence must have a transitive verb and a subject and object, both expressed as nouns.

2. In Mayan languages, the sentence is simple rather than complex (or at least the clause is a main clause).

3. The verb must be indicative, affirmative, and active.

4. The sentence should have an interchangeable subject and object.

5. Sentences should not be ambiguous in interpretation of subject and object.

6. No constituent is focused, topicalized, or otherwise highlighted.

7. In Mayan, the subject noun is definite.

8. In Mayan, the subject noun is animate.

9. Frequency of natural occurrence is NOT a requirement for basic word order.

10. Morphological marking may provide evidence for $\mathrm{BCO}$.

11. Elicitation is necessary in addition to text analysis.

Many aspects of England's definition are reasonably uncontroversial. The basic word order of a language is generally considered to be the least morphologically marked (Hawkins 1983); it is assumed to be "pragmatically neutral" (Pullum 1977); and it is based on simple, declarative, active 
clauses with no complex verb or verb phrases (Chomsky 1957, Greenberg 1966, and Pullum 1981b).

There are, however, some aspects of England's definition which are more controversial. One obvious problem is the use of the hedge "In Mayan, . . .." If the concept of $\mathrm{BCO}$ is viable, it must be universally applicable. There should not be separate concepts of BCO for different linguistic families (one for Mayan, one for Uto-Aztecan, one for Oto-Manguean, etc.), although the concept may be of greater relevance for some families (e.g., Mayan) than for others (e.g., Pama-Nyungan). Fortunately, few problems arise if England's hedge is simply disregarded. It is unnecessary, provided that the concept of basic word order is anchored to the concept of a prototypical transitive clause, which is generally believed to possess an animate and definite subject and to be affirmative, indicative active, etc. (see Hopper and Thompson 1980).

The criterion that subject and object (henceforth " $A$ " and " $O$," respectively) must be interchangeable is also problematic. (Here I employ Dixon's [1979; 1994] three-way division of core arguments into S, the single core argument of an intransitive clause; $A$, the core argument of a transitive clause that it is prototypically associated with the agent; and $\mathrm{O}$, the core argument of a transitive clause that it is prototypically associated with the patient. See Andrews [1985] for further discussion and justification.) England includes this criterion because such sentences have the greatest requirement for the use of word order to determine the assignment of semantic roles. Sentences with interchangeable A's and O's tend to be those where $\mathrm{A}$ and $\mathrm{O}$ are equal in animacy; however, such sentences are actually fairly unusual (and are probably not "pragmatically neutral"), since it has been shown in a number of studies that A normally outranks $O$ in animacy (Comrie 1989:128). This brings us to England's position with respect to frequency of occurrence.

England notes that her criteria are very restrictive and single out a set of sentences that will be fairly uncommon in naturally occurring speech. However, if frequency of natural occurrence is not a requirement for $\mathrm{BCO}$, what role does statistical analysis play in considerations of BCO? A number of authors have taken quite a different position with respect to the relationship of basicness to frequency. Greenberg (1966:67) explicitly anchors BCO to frequency (as does Hawkins 1983). Dryer (1995) provides a more subtle position, which distinguishes markedness from frequency of occurrence. With growing interest in the role that patterns of usage play in shaping grammar (Hopper 1987 and DuBois 1987), considerations of statistical trends in usage should not be dismissed out of hand.

Here, I tackle constituent order from the vantage point of information structure, bringing to bear on the problem not only statistical data from 
textual analysis but also more traditional analysis of grammatical structure. By considering the frequency of different constituent orders in discourse, I am rejecting England's claim that frequency is irrelevant. However, I do not commit myself to any particular view of what type of relationship should exist. In the end, it appears that, in Tenejapa Tzeltal, all of the various criteria converge on VOA as the $\mathrm{BCO}$ of the language.

2.2. The BCO of Tenejapa Tzeltal. Previous work on Tenejapa Tzeltal constituent order has been restricted to the alternation between VOA and VAO constituent order, which is allegedly determined by the relationship between $A$ and $O$ on a hierarchy of animacy (Smith 1975, Norman and Campbell 1978, and Dayley 1981). On the basis of elicited data from Smith (1975), Norman and Campbell (1978) put forward a disjunctive statement of Tenejapa Tzeltal's BCO, claiming that it is VOA when A > O in animacy and VAO when $A=O$ in animacy. (Nothing is said concerning sentences where $\mathrm{O}>\mathrm{A}$ in animacy.) Dayley (1981:43) essentially repeats their analysis in his overview of voice and ergativity in Mayan: "word order differs depending on the status of the $A$ and [O] on the animacy hierarchy: if $A$ equals [O] the order is $\mathrm{VA}[\mathrm{O}]$; if $\mathrm{A}$ is higher than [O] the order is $\mathrm{V}[\mathrm{O}] \mathrm{A} . " 5$

Dayley (1981:43) illustrates these putative constituent ordering principles with the following example sentences: ${ }^{6}$

$\begin{array}{lllll}\text { la } & s-\text { mil- } \emptyset & \text { Jpetul } & \text { te } & \text { Jwan } \\ \text { CP } & 3 \mathrm{E}-\mathrm{kill}-3 \mathrm{~A} & \text { Peter } & \text { ART } & \text { John }\end{array}$

'Peter killed John'.

$\begin{array}{lllllll}\text { la } & s \text {-t'om- } \emptyset & \text { ta } & \text { ti'el } & t z^{\prime} i & \text { te } & \text { baka } \\ \text { CP } & 3 \mathrm{E}-\mathrm{bite}-3 \mathrm{~A} & \text { with } & \text { teeth } & \mathrm{dog} & \text { ART } & \text { cow }\end{array}$

'The dog bit the cow (with teeth)'.

(3) la s-mil- $\emptyset$ baka te Jpetul-e

CP 3E-kill-3A cow ART Peter-ENC

'Peter killed the cow'.

(4) la s-maj- $\emptyset$ y-inam te Jpetul-e

ICP 3E-hit-3A 3E-wife ART Peter-ENC

'Peter hits his wife'.

${ }^{5}$ Dayley employs alternative notation (P rather than $\left.\mathrm{O}\right)$. His P's have been replaced by O's here for the sake of consistency.

${ }^{6}$ The following abbreviations are used in morphemic glosses: $\exists$ exists; $\nexists$ does not exist; 1 first person; 2 second person; 3 third person; A absolutive; ANT anteriority; ART definite article; AUX auxiliary; AGT agentive; BEN benefactive; CAUS causative; COM comitative; COMP complementizer; CP completive; DEM demonstrative; DES desiderative; DIR directional; E ergative; EMP emphatic; ENC enclitic; HS hearsay; ICP incompletive; IRR irrealis; NEG negative; NM nominalizer; NT neutral; P preposition; PASS passive; PL plural; PN proper noun; PT particle; REM remote; RN relational noun; SG singular; STAT stative; TOP topicalizer. 
However, there are a number of problems with this analysis. In the first place, there are some minor errors that call into question the validity of the data upon which the animacy account is based. The name Jwan comes as a borrowing from Spanish, and not from Tenejapa Tzeltal, where the equivalent name is Jxun (note that the initial / $\mathrm{j} /$ is a prefix used with all male names), and (1) and (2) both lack the enclitic $-e$, even though the definite article te must co-occur with this enclitic in NPs that occur sentence-finally.

A second and much more serious problem with these claims is counterevidence from texts. In (5)-(8), VAO constituent order is predicted, given that $\mathrm{A}=\mathrm{O}$ in animacy, but VOA constituent order is found instead:

(5) la $x$-chik'-ik- $\emptyset$ j'ijk'al te antiwo j-mam

CP 3E-seize-PL-3A blk.demon ART ancient 1E-male

j-me'-chunil-e

$1 \mathrm{E}$-female-grandparent-ENC

'Our ancient ancestors burnt up the black demon'. (Stross 1978:6).

(6) te namej k'inal-e la s-tzak- $\emptyset$ bel antz

ART olden day-ENC CP 3E-carry-3A DIR woman

j-chamo' ta $x$-ch'en j'ijk'al

AGT-Chamulan $P$ 3E-cave blk.demon

'Long ago a black demon carried a Chamulan woman off to his

Cave'. (Stross 1978:3)

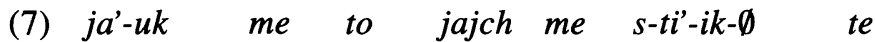
EMP-IRR DES still AUX DES 3E-eat-PL-3A ART

k'ulub-etik-e te mut-etik-e, te tz'i'etik-e, locust-PL-ENC ART chicken-PL-ENC ART dog-PL-ENC

te mis-etik-e

ART cat-PL-ENC

'Chickens, dogs, and cats ate locusts'. (Pérez López and Gómez Ramírez [henceforth Pérez and Gómez] 1986:51)

(8) te k'alal la la s-ta-ix- $\emptyset$ na-etik a

COMP when CP HS 3E-find-3A-already house-PL DEM

te ja'-e, jich lok'-ik- $\emptyset$ la ta anel

ART water-ENC thus leave-PL-3A HS P hurry

te y-ajwal-e

ART 3E-owner-ENC

'When the waters reached the houses, their owners began to leave in a hurry'. (Méndez López and Méndez Guzmán 1992:45) 
In light of these sentences, it is worth saying a few words about the nature of animacy. From Dayley (1981), it seems that the following animacy hierarchy is taken for granted:

\section{(9) HUMAN > ANIMATE > INANIMATE}

Applying this hierarchy to (5)-(8) above is not entirely straightforward, since there may be disagreement over the classification of the j'ikal, mythological black demonlike creatures that are the subject of many folktales in Tzeltal. However, the contrast between (5) and (6) is crucial, since it shows that when one of the core arguments of a transitive clause is a $j^{\prime} i k^{\prime} a l$ and the other is human, VOA constituent order is found, regardless of whether the $j^{\prime} i k^{\prime} a l$ acts on a human, as in (6), or vice versa, as in (5). ${ }^{7}$ Furthermore, (8) is clear-cut: both of the entities are inanimate, yet VOA is found.

Finally, one of the examples cited in Dayley (1981) appears to be inconsistent with the proposed constituent ordering principle. In (4), both of the entities involved are equal in animacy, yet the constituent order is VOA (where VAO would be predicted). Dayley (1981) fails to note this inconsistency. Norman and Campbell (1978) identify it, but salvage the animacybased account with the ancillary claim that, although the NP te jpetule 'Peter' in (4) appears on the surface to be $A$, it is actually the possessor, which controls the deletion of $A .{ }^{8}$ In other words, they claim that the surface order is misleading due to bracketing ambiguity. This salvages the claim for VAO constituent order, since underlying VAO constituent order would also give rise to surface VOA constituent order.

However, this analysis is highly questionable. There is no independent evidence that possessor-controlled deletion exists in Tzeltal, which makes the analysis somewhat ad hoc, especially given that an underlying VOA constituent order would also give rise to surface VOA constituent order as a result of possessor-controlled deletion, as shown in figure 1.

Furthermore, there is good evidence for an underlying VOA constituent order from examples like (10) and (11), where there is no bracketing ambiguity, since the possessor of $\mathrm{O}$ is not third person and the constituent order is clearly VOA. ${ }^{9}$

\footnotetext{
${ }^{7}$ There are other arguments in favor of the "humanness" of the j'ik'al-for example, they take the same numeral classifier as humans (-tul).

${ }^{8}$ It cannot be argued that males outrank females in animacy in Tenejapa Tzeltal since the same ordering is found when gender roles are reversed (e.g., 'Mary hits her husband').

${ }^{9}$ In both (10) and (11), the absolutive suffixes on the verb cross-index the possessor due to possessor raising.
} 


\begin{tabular}{|ccc|}
\hline Underlying Order & \multicolumn{3}{|c|}{ Surface Structure } \\
\hline VOA & $\overbrace{\text { ya smaj }}^{\mathrm{V}} \overbrace{\text { yinam [te jpetule }]_{\mathrm{i}}}^{\mathrm{O}} \overbrace{\hat{\emptyset}_{\mathrm{i}}}^{\mathrm{A}}$ \\
\hline VAO & $\overbrace{\text { ya smaj }}^{\mathrm{V}} \overbrace{\hat{\emptyset}_{\mathrm{i}}}^{\mathrm{A}} \overbrace{\text { yinam }[\text { te jpetule }]_{\mathrm{i}}}^{\mathrm{O}}$ \\
\hline
\end{tabular}

FIG. 1.-Two underlying structures for (4) in text.

$\begin{array}{llllll}\text { (10) laj } & \text { me } & y \text {-elk'an-be-n-ix } & \text { tel } & k \text {-al } & t e \\ \text { CP } & \text { DES } & \text { 3E-steal-BEN-1A-ANT } & \text { DIR } & \text { 1E-child } & \text { ART }\end{array}$

j'ijk'al-e

blk.demon-ENC

'The black demon carried away my child'. (Ramírez Hernández 1994:129)

(11) $y a$ wan $x$-tal $y$-a'y-be-t $\quad a^{\prime} w$-a'tel

ICP perhaps NT-AUX 3E-understand-BEN-2A 2E-work

tz'in yan kirsano ch'i

then another person eh

'Perhaps some other person would come do your work then, eh?' (Stross 1979:116)

It seems, then, that transitive clauses with a possessed $O$ are evidence against an account of Tenejapa Tzeltal's BCO in terms of animacy after all.

Since previous claims concerning constituent order in Tenejapa Tzeltal are on shaky ground, more in-depth investigation of constituent ordering in the language is called for. In 3, I show that VAO constituent order is vanishingly rare and certainly a nonstarter for the $\mathrm{BCO}$ of the language.

\section{Quantitative corpus analysis.}

3.1. The corpus. In order to examine constituent ordering and elision in narrative discourse, a corpus of 20 narrative texts (folktales) was tagged and analyzed. ${ }^{10}$ Half of these texts are spoken narratives recorded and transcribed by Stross $(1977 ; 1978 ; 1979)$ and half are narratives written by native speakers with accompanying Spanish translations (Pérez and Gómez 1986). To give some idea of the size of the corpus, it contains approximately 4,631

${ }^{10}$ Almost all of these texts were originally scanned by Penelope Brown. Her generosity in sharing these electronic materials is gratefully acknowledged. 
TABLE 1

NarRative Texts IN CORPUS

\begin{tabular}{ll}
\hline \hline Narrative Text & \multicolumn{1}{c}{ Source } \\
\hline "Alligator" & Stross (1978) \\
"Backwards Foot" & Stross (1978) \\
"Black Demon" & Stross (1978) \\
"Black Demon and Chamula Woman" & Pérez and Gómez (1986) \\
"Black Demon Killed with Chili" & Stross (1978) \\
"The Church" & Pérez and Gómez (1986) \\
"The Curer" & Pérez and Gómez (1986) \\
"The Flood" & Pérez and Gómez (1986) \\
"Kokonutsu" & Stross (1979) \\
"Kulub" & Pérez and Gómez (1986) \\
"The Persecution" & Pérez and Gómez (1986) \\
"Possum and Puma" & Stross (1977) \\
"The Priest" & Pérez and Gómez (1986) \\
"Rabid Demon" & Stross (1978) \\
"Rooster and Sparrow" & Pérez and Gómez (1986) \\
"Severed Head" & Stross (1978) \\
"The Spook" & Pérez and Gómez (1986) \\
"The Black Demon" & Stross (1978) \\
"Trip to Hell" & Stross (1978) \\
"The Patron Saint Alonso or Idelfonso" & Pérez and Gómez (1986) \\
\hline
\end{tabular}

clauses, 909 of which are transitive clauses of some variety. ${ }^{11}$ Table 1 lists the texts that make up the corpus.

Each text was annotated using a number of special tags (designated by a left curly bracket) that were inserted before the constituents under analysis. Table 2 provides a summary of the tags that were used in the markup of the corpus.

The following excerpt from a story entitled "Alligator" (Stross 1978:21) illustrates the nature of the markup scheme: ${ }^{12}$

I/ te namej k'inale ay laj a $\{$ I.p bik'ot $\{\mathrm{A}$ ain $\{\mathrm{O}$ jtul winik

In the olden days there was a man (who) was swallowed by Alligator.

// yu'un laj \{I bajt ta stzakel puy $\left\{\mathrm{S}^{*}\right.$

It was because he had gone to catch snails (for eating).

${ }^{11}$ This number is approximate and underestimates slightly the size of the corpus, since it is actually a count of the number of lines in the corpus and some lines contain more than a single clause.

${ }^{12}$ Note that $\mathrm{A}$ and $\mathrm{O}$ are used as tags in passive clauses. They should be taken as labels for the prederivational status of these arguments. Therefore, $\mathrm{A}$ and $\mathrm{O}$ correspond to oblique agent and $S$, respectively, after passivization. 
TABLE 2

TAGS UsEd IN CORPUS

\begin{tabular}{ll}
\hline \hline Tag & \multicolumn{1}{c}{ Meaning } \\
\hline$\{\mathrm{R}$ & Reflexive object \\
$\{\mathrm{T}$ & Transitive verb \\
$\{\mathrm{I}$ & Intransitive verb \\
$\{\mathrm{S}$ & $\mathrm{S}$ \\
$\{\mathrm{O}$ & $\mathrm{O}$ \\
$\{\mathrm{A}$ & $\mathrm{A}$ \\
$\{\mathrm{C}$ & Complement clause \\
$\mathbf{p}$ & Passive \\
$*$ & Elided \\
1 & First person \\
2 & Second person \\
\hline
\end{tabular}

I/ te Kalal laj a \{I lijk ta stzakel te puye $\left\{\mathrm{S}^{*}\right.$

When he began to gather the snails

I/ ta sbabi laj la $\left\{\mathrm{T}\right.$ slok'es $\left\{\mathrm{O}\right.$ sk'u' $^{\prime} \mathrm{A}^{*}$

first he took off his chamarra.

I/ la laj \{ $\mathrm{T}$ stilp'un te \{O sk'u'e $\left\{\mathrm{A}^{*}\right.$

He untied (the sash belt holding) his chamarra.

Quantitative information was extracted from the corpus electronically using regular expression pattern-matching (Friedl 1997) as well as custom-made Icon programs (Griswold and Griswold 1997).

3.2. Criteria for inclusion. Three types of transitive clauses were systematically excluded from consideration, since they do not conform to the generally agreed upon criteria for BCO discussed in 2.1. First, transitive clauses with reflexive O's (which take the form of an obligatorily possessed dummy reflexive noun, $b a$ ) or complement clauses were excluded (although clauses with an elided $\mathrm{O}$ were included). Second, since active clauses are our main concern, all passive clauses in the corpus were excluded from analysis. Third, transitive clauses with first- or second-person arguments were excluded, since first- and second-person arguments take the form of unbound/independent pronouns only for emphatic or contrastive usage. ${ }^{13}$ (Tenejapa Tzeltal does not possess third-person pronouns and could be classified as "pro-drop.") The remaining transitive clauses were analyzed for patterns of elision and constituent ordering. Unless otherwise stated, all

\footnotetext{
${ }^{13}$ Independent pronouns for "local" person (i.e., first or second person) core arguments are vanishingly rare. In 148 transitive clauses with one or more local person core argument(s), only 4 (3\%) make use of an independent pronoun for the local person core argument.
} 
TABLE 3

Frequency of Transitive Clause Types in Corpus

\begin{tabular}{lcc}
\hline \hline Type of Transitive Clause & Percentage & Raw Number \\
\hline Canonical transitive clauses & $54.4 \%$ & 495 \\
Reflexive clauses & $5.7 \%$ & 52 \\
Complex clauses & $15.3 \%$ & 139 \\
Passive clauses & $5.2 \%$ & 47 \\
"Local" person argument & $19.4 \%$ & 176 \\
Total & $100 \%$ & 909 \\
\hline
\end{tabular}

TABLE 4

Lexical Arguments in Transitive Clauses

\begin{tabular}{|c|c|c|}
\hline $\begin{array}{c}\text { Number of } \\
\text { Lexical Arguments }\end{array}$ & Percentage & Number \\
\hline 0 & $22.6 \%$ & 112 \\
\hline 1 & $56.8 \%$ & 281 \\
\hline 2 & $20.6 \%$ & 102 \\
\hline Total & $100 \%$ & 495 \\
\hline
\end{tabular}

subsequent references to "transitive clauses" in the corpus refer to these transitive clauses. Table 3 summarizes the distribution of the various types of transitive clauses found in the corpus.

Of the 495 transitive clauses found in the corpus that fulfill the necessary criteria for investigation, relatively few possessed two full lexical arguments. The relative frequency of transitive clauses with zero, one, or two full lexical arguments is given in table 4.

Note that the number of clauses with zero or two lexical arguments is quite similar, although clauses with one lexical argument are by far the most frequent. This is unusual, considering that previous findings based on narrative texts show a much higher number of clauses with zero lexical arguments and a much lower number of clauses with two lexical arguments. DuBois (1987), for example, found that transitive clauses with two lexical arguments represent only $3 \%$ of the 179 transitive clauses in his corpus of Sacapultec (Mayan) spoken narratives. ${ }^{14}$

4. Results. In this section, I discuss the results of quantitative analysis of the corpus. Since clauses with two lexical arguments are our main concern, I discuss them first (4.1). However, clauses with a single lexical argu-

\footnotetext{
${ }^{14}$ However, results similar to those found for Tzeltal emerged from a study of spoken narrative texts in the Zinacanteco dialect of Tzotzil (Tzeltal's sister language), where transitive clauses with two lexical arguments represented $12 \%$ of the 305 transitive clauses examined
} 
TABLE 5

Constituent Order in Transitive Clauses with Two LEXICAL ARguments

\begin{tabular}{ccc}
\hline \hline Constituent Order & Percentage & Number \\
\hline VOA & $65.7 \%$ & 67 \\
AVO & $31.4 \%$ & 32 \\
OVA & $2 \%$ & 2 \\
VAO & $0.9 \%$ & 1 \\
AOV & $0 \%$ & 0 \\
OAV & $0 \%$ & 0 \\
Total & $100 \%$ & 102 \\
\hline
\end{tabular}

ment are also examined (4.2). (Obviously, the ordering of constituents is irrelevant in clauses where both $\mathrm{A}$ and $\mathrm{O}$ have been elided.)

4.1. Constituent order with two lexical core arguments. Here, I examine transitive clauses with two lexical arguments. Table 5 lists the frequency of the six possible constituent orderings in the corpus.

Table 5 shows that VOA and AVO constituent orders are the most common for transitive clauses with two lexical arguments. In fact, together they represent over $97 \%$ of all transitive clauses with two lexical arguments. The various orders attested in the corpus are exemplified below:

VOA

(12) $j a$ ' nax laj jich, la laj s-ta- $\emptyset$ alchaxiltik EMP only HS thus CP HS 3E-find-3A orange.orchard te winik-e

ART man-ENC

'Thus it was, the man found an orange orchard'. (Stross 1978:27) AVO

(13) te jent-e la s-tzob-ik- $\emptyset$ te ton-etik-e ART people CP 3E-gather-PL-3A ART rock-PL-ENC

'The people gathered the stones'. (Pérez and Gómez 1986:46) OVA

(14) ti'bal laj la s-ti'-ik- $\emptyset$ te choj-etik-e meat CP HS 3E-eat-PL-3A ART puma-PL-ENC

'It was meat the Pumas ate'. (Stross 1977:21)

(Robinson 1996). It is tempting to attribute the higher number of clauses with two lexical core arguments in the Tzeltal corpus to the use of written texts, but the written texts actually contain fewer of these clauses ( 33 in total) than the spoken texts (69 in total). 
TABLE 6

Elision in Transitive Clauses with One Lexical Argument

\begin{tabular}{|c|c|c|c|}
\hline Lexical Argument & Elided Argument & Percentage & Number \\
\hline $\mathrm{A}$ & $\mathrm{O}$ & $15.0 \%$ & 42 \\
\hline O & A & $85.0 \%$ & 239 \\
\hline Total & & $100 \%$ & 281 \\
\hline
\end{tabular}

VAO

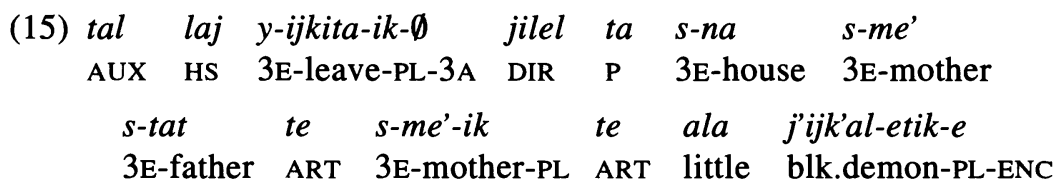

'The mothers $s_{i}$ of the little black demon boys came and left them at the houses of their $i_{i}$ parents'. (Stross 1978:3)

AOV and OAV constituent orders are exceedingly rare, as can be seen from the fact that they do not appear even once in the corpus, but they are not impossible in principle. Rather, they are quite rare due to the pragmatic conditions necessary for their felicitous usage (see 5.4 below).

It seems, then, that there are two contenders for Tzeltal's BCO: VOA and AVO. However, VOA order is potentially a better candidate for BCO, since it is significantly more frequent. Before considering other reasons VOA is a better candidate, I examine transitive clauses with a single lexical argument to determine whether they are consistent with these findings.

\subsection{Constituent order in transitive clauses with a single lexical core} argument. The first question that must be answered when examining transitive clauses with a single lexical argument is which argument-A or $\mathrm{O}-$ is elided in those clauses. The answer is clear. As table 6 shows, it is A (rather than $\mathrm{O}$ ) that is elided in the majority of cases.

In fact, table 6 shows that elision of $A$ is overwhelmingly more frequent: $A$ is elided about six times as frequently as $O$ in transitive clauses with a single lexical argument. This finding is explained largely by the fact that Tzeltal works in terms of a nominative-accusative pivot for coreferential omission of arguments in topic chains (Dixon 1994), in keeping with a widespread cross-linguistic tendency for S and A to be pronominalized or elided in discourse (Prince 1981, Chafe 1987, and Lambrecht 1986). Conversely, the fact that $O$ is lexical more often than $A$ also relates to the wellestablished finding that $O$ is used more frequently than $A$ to introduce new referents, which are necessarily lexical (DuBois 1987). 
TABLE 7

Constituent Order with One Lexical Argument

\begin{tabular}{|c|c|c|}
\hline Constituent Order & Frequency & Number \\
\hline VO & $80.8 \%$ & 227 \\
\hline VA & $9.2 \%$ & 26 \\
\hline $\mathrm{AV}$ & $5.7 \%$ & 16 \\
\hline OV & $4.3 \%$ & 12 \\
\hline Total & $100.0 \%$ & 281 \\
\hline
\end{tabular}

I turn now to constituent order in transitive clauses with a single lexical argument. The relative frequency of the various constituent orders found in such clauses is provided in table 7 .

Table 7 shows that VO order is by far the most common. This is consistent with the findings from the previous section, where the two most frequent constituent orders (VOA and AVO) both involve an immediately postverbal $0 .{ }^{15}$ In addition, a higher number of clauses show VA rather than AV constituent order, but the difference is slight (and probably not statistically significant).

Each of the four ordering types is illustrated below:

VO

(16) ta s-babi laj la s-lok'-es- $\emptyset \quad s-k^{\prime} u^{\prime}$

$P$ 3E-first CP HS 3E-leave-caus-3A 3E-chamarra

'First he took off his chamarra'. (Stross 1978:21)

VA

(17) $j a^{\prime}$ nax laj jich ya laj s-mak'lin- $\emptyset$ te

EMP earlier HS thus ICP HS 3E-care.for-3A ART

y-ajwal na-e

3E-owner house-ENC

'Thus it is, the owner of the house takes care of him'. (Stross 1978:6)

AV

(18) ja'uk me to, te winik-e la s-maj- $\emptyset$ ta echej EMP-IRR DES still ART man-ENC CP 3E-hit-3A P ax

'Then the man hit him with his ax'. (Pérez and Gómez 1986:40-42)

\footnotetext{
${ }^{15}$ This finding is consistent with the principle of "verb-object bonding," which holds that "the object of a transitive clause is syntactically and semantically more tightly 'bound' to the verb than is the subject of a transitive clause" (Tomlin 1986:73).
} 
OV

(19) sok laj te $x$-chujkil-e $x$-chuk-oj- $\emptyset$ laj ta $x$-ch'ujt and HS ART 3E-belt-ENC 3E-tie-STAT-3A HS P 3E-belly

'And his belt, he had tied it around his belly'. (Stross 1978:21)

In summary, whenever a transitive clause possesses only a single lexical argument, it is significantly more likely to appear after the verb than before it. This is true mainly for O's. In the case of A's, there is more mobility with respect to the verb, with only a small preference for them to occur postverbally. These findings are therefore consistent with those of the previous section and suggest that a unitary account can be provided for the constituent ordering of transitive clauses with one or more lexical core arguments.

In the following section, I consider the pragmatic motivation for these constituent order alternations and attempt to provide a more comprehensive statement of the principles of constituent ordering found in the language. I show that departures from VOA are associated with topicalization, focus, and/or indefiniteness, providing additional evidence that VOA constituent order is basic.

5. Information structure in Tenejapa Tzeltal. In the previous section, we saw that on the basis of frequency there are perhaps two competitors for the BCO of Tzeltal: AVO and VOA. However, VOA is twice as frequent as AVO. The data from transitive clauses with a single lexical argument show an overwhelming bias in favor of VO constituent order but are fairly equivocal with respect to the position of $A$. Additional evidence in favor of the "basicness" of VOA constituent order comes from the fact that core NPs appear preverbally only in restricted conditions, which are pragmatically governed (i.e., discourse-related). This is not surprising since, as Aissen (1992:44) has observed, within the Mayan family, preverbal orders tend to be controlled by logical and discourse-level relations (e.g., topic, focus, etc.), while postverbal orders tend to be controlled by properties of individual NPs (e.g., definiteness, animacy, etc.). In the following sections, I attempt to account for the occurrence of preverbal NPs in terms of "information structure." Three factors account for preverbal arguments and are therefore examined in some detail: topicalization (5.1), focus (5.2), and indefiniteness (5.3). Note, however, that topicality alone accounts for the vast majority of preverbal arguments.

\subsection{Topicalization.}

5.1.1. Topics in Tenejapa Tzeltal. Tzeltal possesses a preverbal position which can be characterized as a topic position, given that it appears to be used for a number of pragmatic purposes typically associated with 
topicality, including topic contrast, topic initiation, and topic resumption. Before we proceed, a few words should be said concerning the notion of topic, which has been defined in various ways by different authors. The notion of topic intended here is that of Lambrecht (1994:131): "A referent is interpreted as the topic of a proposition if in a given situation the proposition is construed as being about the referent, i.e. as expressing information which is relevant to and which increases the addressee's knowledge of this referent."

What I will be referring to as Tenejapa Tzeltal's topic position is a syntactic position that is reserved exclusively for topics. It is worth stressing at the outset that the existence of a topic position does not necessitate that all topical NPs appear there. In other words, if an NP appears in the topic position of a sentence, it must be interpreted as topic, but if an NP is the topic, it does not necessarily have to appear in the topic position.

Since the topic position explicitly flags an NP as topic, its use is expected in contexts where it is necessary to establish or reestablish the topic-that is, in situations where two entities are explicitly contrasted (topic contrast), in situations where the topic has changed (topic switch), or in situations where a topic is being reintroduced into discourse (topic resumption). ${ }^{16}$ Each of these uses of the preverbal topic position is illustrated in turn.

The use of a preverbal position for the explicit contrast of two entities is illustrated in (20a) and (20b), which are taken from a story about hell. An explicit contrast is being made here between the treatment received by $t e$ antzetike 'women' and te winiketike 'men', which occur in preverbal positions.

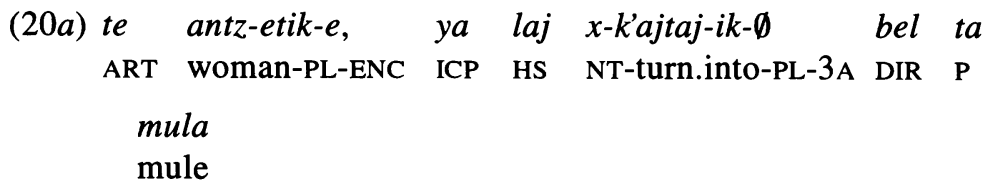

'Women, they get turned into mules'.
(20b) te winik-etik-e, ya laj $x$-k'ajtaj-ik- $\emptyset$ bel ta ART men-PL-ENC ICP HS NT-turn.into-PL-3A DIR P machu ek mule also

'And men, they get turned into (male) mules also'. (Stross 1977:9)

\footnotetext{
${ }^{16}$ Topic initiation is somewhat less straightforward, since it is not necessary explicitly to mark an NP as topic if it does not compete with other entities for topichood (Mithun 1992:47). Therefore, I restrict my attention to the more clear-cut cases.
} 
The use of a preverbal position for topic switch is illustrated in (21a)(21e), which represent the beginning of a story about the persecution of Christ. The story begins with Christ as topic but switches to the devil in (21e) after he is introduced as a passive agent in (21d).

$\begin{array}{rlll}\text { (21a) ja' } & \text { te antiwo } & \text { a'yej to } \\ \text { EMP } & \text { ART } & \text { old } & \text { story still }\end{array}$

'This story is very old'

(21b) ja' niwan te s-babial te bin a k'ot- $\emptyset$

EMP perhaps COMP 3E-first ART what REM arrive-3A

ta pas-el-e

$P$ do-NM-ENC

'and could have been the first thing that came to happen in the world'.

(21c) $y$-u'un ja' s-k'oplal te bit'il la y-ich'- $\emptyset$

3E-RN EMP 3E-story ART how CP 3E-receive-3A

nutz-el te j-ch'ul-tat-tik-e

chase-NM ART 1E-holy-father-1E.PL-ENC

'Because it is the story of how Our Celestial Father got chased'.

(21d) $a k^{\prime}-b-o t-\emptyset$

kastiko sok utz'in-ot- $\emptyset \quad y$-u'un

give-BEN-PASS-3A punishment and mistreat-PASS-3A 3E-RN

te pukuj-e

ART devil-ENC

'He was punished and mistreated by the devil'.

(21e) te pukuj-e ja' me la s-nutz- $\emptyset$ te

ART devil-ENC EMP DES CP 3E-chase-3A ART

j-ch'ul-tat-tik-e

1E-holy-father-1E.PL-ENC

'The devil, he chased our Holy Father'. (Pérez and Gómez 1986:19)

Topic resumption can be illustrated by the stretch of discourse given in (22a)-(22e), where the narrator is discussing the actions of a group of mischievous possums. In (22a), the narrator sets the scene, using VOA constituent order. Two transitive clauses ( $22 b$ and $22 c$ ) follow in which the subject is elided, being inferable from context. There is then a one-clause hiatus from the topic in $(22 d)$, which is resumed in (22e) with a full NP that precedes the verb, giving AVO constituent order. 


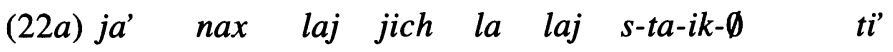
EMP only HS thus CP HS 3E-find-PL-3A edge

uk'um te j'uch-etik-e

river ART possum-PL-ENC

'Thus it was, the possums reached (literally: found) the riverbank'.

(22b) la laj s-toy- $\emptyset$ bel sit-ik ta jejch uk'um

CP HS 3A-raise-3A DIR eye-PL $P$ side river

'They raised their eyes to the (other) side of the river'.

$$
\begin{aligned}
& \begin{array}{lllllllll}
l a & \text { laj } & y \text {-il-ik- } \emptyset & a y & \text { laj } & a & \text { tal } & \text { jbel } & \text { ta } \\
\text { CP } & \text { HS } & \text { 3E-See-PL-3A } & \exists & \text { HS } & \text { REM } & \text { come } & \text { traveler } & \text { P }
\end{array} \\
& \text { jejch } u k^{\prime} u m \\
& \text { side river }
\end{aligned}
$$

'They saw that there was a traveler that had come to the (other) side of the river'.

(22d) $x$-che'bal laj tal sok y-inam te jbel-e

3E-two HS come with 3E-wife ART traveler-ENC

'Two of them had come, the traveler and his wife'.

$$
\begin{array}{llllll}
\text { (22e) te } & \text { j'uch-etik-e } & \text { la } & \text { laj } & \text { s-lo'lo-ik- } \emptyset & \text { xan } \\
\text { ART } & \text { possum-PL-ENC } & \text { CP } & \text { HS } & \text { 3E-deceive-PL-3A } & \text { again } \\
\text { te } \quad j b e l-e & & & & \\
\text { ART } & \text { traveler-ENC } & &
\end{array}
$$

'And so the Possums deceived the traveler again'. (Stross 1977:22)

5.1.2. The grammar of topics. In the previous section, I established that there is a preverbal topic position in Tenejapa Tzeltal but made little attempt to pin down more precisely its syntactic behavior. In this section, I consider the syntax of topicalization in more detail, using as a starting point Aissen's (1992) analysis of topic and focus in Tzotzil.

In Tzotzil, there are four ways that the topic position can be identified (Aissen 1992:49). Topicalized NPs in Tzotzil: (1) occupy a sentence-initial position; (2) are preceded by the particle ' $a$; (3) occur with the articles $l i$ and $t i$ and the demonstrative $t a j$ (which are accompanied by the enclitic $-e$ ); and (4) can be followed by the particle 'un. All of these features are present in the Tzotzil example in (23), where the NP krem 'boy' occupies the topic position and occurs with the article $t i$. 
(23)
'a-ti krem 'un-e i- Ø-k'ot
ta s-na
TP-ART boy
PT-ENC
CP-3A-arrive
$P$ 3E-house PT

'As for the boy, he arrived home'. (Laughlin 1977:228)

These criteria more or less carry over to Tzeltal, where there are three features that enable identification of the topic position. Topics in Tzeltal: (1) can be preceded by the particle in; (2) occur with the definite article $t e$; and (3) precede the emphatic particle $j a$ ' (when present).

The article $t e$ obligatorily occurs with topicalized arguments, but it can also appear with focused arguments, which means this criterion by itself cannot uniquely identify topicalization. What appears to be unique to topicalized arguments in Tenejapa Tzeltal is the use of the (optional) particle in, as in (24). ${ }^{17}$

$$
\begin{aligned}
& \text { in te toro-e la s-lok'es- } \emptyset \text { ta s-lotz' } \\
& \text { TOP ART bull-ENC CP 3E-leave-CAUS-3A P 3E-neck } \\
& \text { te j-ch'ul k-ajwal-tik-e } \\
& \text { ART 1E-holy 1E-lord-E.1PL-ENC }
\end{aligned}
$$

'And the bull, he let the Holy Father out from his neck'. (Pérez and Gómez 1986:20)

Elicitation reveals that this particle is restricted to topicalized arguments and is ungrammatical when used in conjunction with postverbal NPs, as shown by the ungrammaticality of (25). ${ }^{18}$

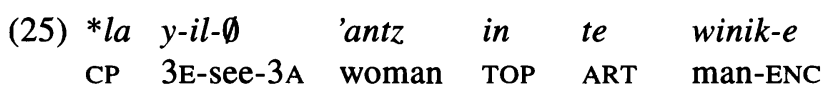

'The man saw the woman'.

Finally, it appears that all core argument types can be topicalized, as demonstrated by the following sentences, where (26) demonstrates topicalization of S; (27) topicalization of A, and (28) topicalization of $\mathrm{O}$.

$S$

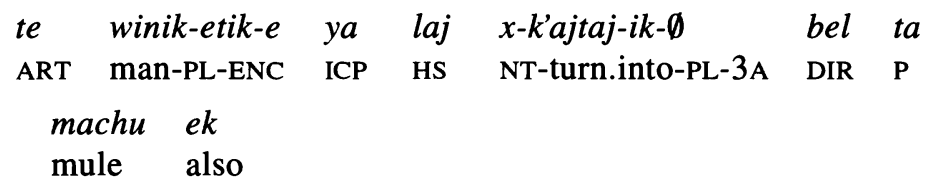

'And men, they get turned into (male) mules too'. [=(20b)]

${ }^{17}$ Also note that the use of the particle in rules out a narrow focus reading (5.2). Therefore, (24) could not be interpreted as 'It was a bull that let the Holy Father out from his neck', even if the context permitted such a reading.

${ }^{18}$ Example sentences without citation information come from my fieldwork in Chiapas during 1999, principally from native speaker Pedro Hernández Guzmán. 
A

(27) te kaxlan-etik-e ja nix jich la s-pas-ik- $\emptyset$ ART ladino-PL-ENC EMP even thus CP 3E-do-PL-3A

'Even the ladinos had to do it'. (Pérez and Gómez 1986:51)

$\mathrm{O}$

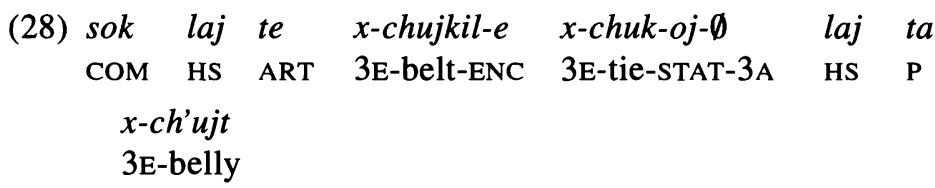

'And his belt, he had tied it around his belly'. [=(19)]

Since the topic position is pivotless (i.e., is not restricted to a particular subset of grammatical roles), a topicalized NP can, in the right context, correspond to either A, as in (27), or O, as in (28). However, AVO constituent order is much more frequent than OVA order, due primarily to the topicalization of A (which makes sense in light of the strong association between subjecthood [S/A] and topicality [DuBois 1987, Comrie 1989, and Dixon 1994]).

\subsection{Narrow focus.}

5.2.1. Characterizing focus presupposition. The association of narrow focus with a clause-initial position provides another insight into the departures from VOA constituent order found in the corpus. By narrow focus, what is meant are "focus presupposition sentences"-that is, sentences where the focused constituent corresponds to an open variable in a presupposed proposition-e.g., in English, It's the legislative branch that interprets the law.

In Tzeltal, the focus construction involves the fronting of the focused argument, as illustrated by the following examples of negative narrow focus: ${ }^{19}$

(29) ma ba jo'on te la s-maj-on te j-antun-e NEG 1SG ART CP 3E-hit-1A ART PN-Anthony-ENC

'I wasn't the one who Anthony hit'.

(30) ma ba jo'on la j-mil- $\emptyset$ te j-xun-e NEG 1SG CP 1E-kill-3A ART PN-John-ENC

'I wasn't the one who killed John'.

${ }^{19}$ There are two markers of negation used in negative narrow focus: $m a b a$ and $m a$ (the latter co-occurs with the enclitic $-u k$ ). The difference between the two forms is unclear, but the former is generally said to be more "emphatic." The form $m a b a$ is used in these examples because $m a$, when used in conjunction with some pronouns, gives rise to irregular forms-e.g., ma jo'konuk in lieu of the expected *ma jo'onuk. 
The use of the focus construction is illustrated in the following sentence, taken from a story concerning the origins of the sparrowhawk's predation upon chickens. In the story, a rooster reveals to a sparrowhawk the secret whereabouts of the sun. When the sparrowhawk tracks down the sun, it is angered and demands that the sparrowhawk reveal his informant. The sparrowhawk replies as follows:

$$
\begin{array}{rllll}
\text { (31) } j a & \text { te } & \text { tat-mut } & \text { la } & y \text {-al-be-n } \\
\text { EMP } & \text { ART } & \text { father-bird } & \text { CP } & \text { 3E-say-BEN-1A }
\end{array}
$$

'It was the rooster that told me'. (Pérez and Gómez 1986:33)

This example fits the functional profile of a narrow focus construction since the focused constituent (te tat-mut 'the rooster') corresponds to an open variable (the agent) in a presupposed proposition (' $x$ said something to the speaker').

5.2.2. The grammar of narrow focus. The construction used to express narrow focus can be identified by a number of formal distributional criteria. Focused NPs in Tzeltal: (1) occupy a preverbal position; (2) follow the optional emphatic particle $j a^{\prime}$ (when present); and (3) cannot take the demonstrative in.

The topic position can be distinguished from the focus position by its position relative to the emphatic marker $j a$ '. Topicalized arguments precede $j a$, as in (32), while focused arguments follow it, as in (33).

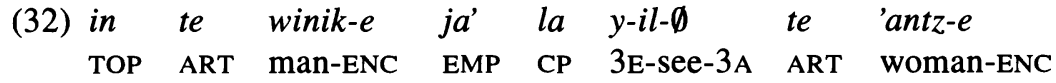
'As for the man, he saw the woman'.

(33) $j a$ ' te winik-e (te) la y-il- $\emptyset$ te 'antz-e EMP ART man-ENC COMP CP 3E-see-3A ART woman-ENC

'The man (rather than someone else) saw the woman'.

Another difference between topic and focus position concerns complement clauses. While there are instances of focus within a complement clause, as in (34), topicalization within complement clauses does not appear to be possible.

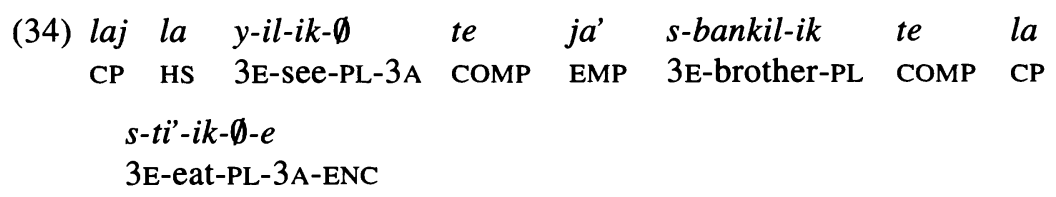

'They saw that it was their brother that they were eating ...'

(Stross 1977:21) 
Narrow focus operates freely without any restrictions in terms of syntactic role. In other words, it is pivotless. Any core argument can therefore be focused: $\mathrm{S}$, as in (35); A, as in (31); or $\mathrm{O}$, as in (37).

$S$

(35) $m a$ ja'uk j-xun te $x$-a'tej- $\emptyset$ ta pinka

NEG EMP-IRR PN-John ART NT-work-3A P farm

'It isn't John (but rather someone else) who works on a farm'.

A

(36) $j a^{\prime}$ te tat-mut la y-al-be-n

EMP ART father-bird CP 3E-say-BEN-1A

'It was the rooster that told me'. [=(31)]

$\mathrm{O}$

(37) us laj te ya s-kuy-ik- $\emptyset$ ta chenek'-e

fly HS ART ICP 3E-believe-PL-3A P bean-ENC

'It's little flies that they take for beans'. (Stross 1977:12)

5.3. Indefiniteness. The association of indefinite arguments with a clause-initial position also provides insight into the departures from VOA constituent order found in the corpus. This is illustrated in (38) and (39) for inanimate and animate indefinites, respectively.

(38) $m a^{\prime} y u k$ bin $y a \quad j-k^{\prime} a n-\emptyset$

$\exists \quad$ what ICP $1 \mathrm{E}-$ want-3A

'I don't want anything'. (Pérez and Gómez 1986:20)

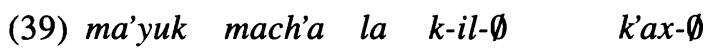

$\exists \quad$ who $C P$ 1E-see-3A pass-3A

'I haven't seen anyone pass by'. (Pérez and Gómez 1986:20)

There are only a few examples of active transitive clauses with indefinite A's. ${ }^{20}$ There are, however, a number of transitive clauses with indefinite A's and complement clauses (rather than true O's), as illustrated in (40) and (41).

${ }^{20}$ This is due in part to the fact that the passive is used in the corpus whenever both A and $\mathrm{O}$ are third-person animates, but $\mathrm{A}$ is indefinite while $\mathrm{O}$ is definite. Whether this is obligatory remains an open question. Tzeltal voice is amenable to an obviation analysis, along the lines of what is proposed for Tzotzil by Aissen (1997). This may therefore be an obviation effect related to definiteness. 
(40) ma'yuk mach'a la y-al- $\emptyset$ te banti la $\exists \quad$ who CP 3E-say-3A COMP where CP $s-t a-i k-\emptyset-e$ 3E-find-PL-3A-ENC

'But no one told him anything about where they got it from'. (Pérez and Gómez 1986:48)

(41) ja'-uk me to 'ay mach'a la $x$-waechin- $\emptyset$ te EMP-IRR DES still $\exists$ who CP 3E-dream-3A COMP bina te ya s-k'an- $\emptyset$ te balumilal-e what ART ICP 3E-want-3A ART wall-ENC.

'That was until someone dreamed what it was the walls were lacking'. (Pérez and Gómez 1986:47)

Finally, it seems that all core argument positions can be occupied by indefinites, as shown by the following sentences: ${ }^{21}$

$S$

(42) $j a$ ' la ya y-il- $\emptyset$ te me 'ay binti ya EMP HS ICP $3 \mathrm{E}-$ see-3A $\begin{array}{lll}x \text {-lok' } \emptyset & \text { ta } & s-b e-e \\ \text { NT-leave-3A } & \text { P } & \text { 3E-road-ENC }\end{array}$

'He saw whether something was leaving along the road'. (Ramírez Hernández 1994:45)

A

(43) ma'yuk mach'a ya s-tzak- $\emptyset$ ta jich nax $\exists \quad$ who ICP 3E-grab-3A $P$ just like this

'Nobody took it just like this'. (Pérez and Gómez 1986:48)

$\mathrm{O}$

(44) $m a$ 'yuk bi ya j-pas- $\emptyset$

$\exists \quad$ what ICP $1 \mathrm{E}-\mathrm{do}-3 \mathrm{~A}$

'I didn't do anything'. (Stross 1977:19)

5.4. Summary. The ordering of indefinite arguments with respect to topicalized or focused arguments remains to be shown. The corpus alone cannot address this issue since it contains no instances of the co-occurrence of topicalization or focus with indefinite arguments. However, elicitation shows that both topicalized and focused arguments precede indefinite arguments, as shown in (45) and (46).

${ }^{21}$ Since there were no instances of indefinite S's in the corpus, (42) was taken from another source. 
$\begin{array}{llllll}\text { (45) te } & j \text {-xun-e } & \text { 'ay } & \text { mach'a } & \text { la } & s-m i l-\emptyset \\ \text { ART } & \text { PN-John-ENC } & \exists & \text { who } & \text { CP } & \text { 3E-kill-3A }\end{array}$

'As for John, he killed someone'.

$\begin{array}{llllll}\text { (46) } j a ' & j \text {-xun } & \text { 'ay } & \text { mach'a } & \text { la } & s \text {-mil- } \emptyset \\ \text { EMP } & \text { PN-John } & \exists & \text { who } & \text { CP } & 3 \mathrm{E}-\mathrm{kill}-3 \mathrm{~A}\end{array}$

'It was John (rather than someone else) who killed someone'.

It is also possible for both topicalization and focus to occur within a single sentence, in which case the topicalized argument precedes the focused one, as in (47).

$\begin{array}{llllll}\text { te } & j \text {-xun-e } & j a & \text { 'ixim } & \text { la } & s-\text { man- } \emptyset \\ \text { ART } & \text { PN-John-ENC } & \text { EMP } & \text { corn } & \text { CP } & \text { 3E-buy-3A }\end{array}$

'As for John, it was corn that he bought'.

In summary, then, the ordering of arguments within a transitive clause is as follows:

$$
\text { (TOPIC) ( } j a^{\prime} \text { ) (FOCUS) (INDEF) V (O) (A) }
$$

This explains the question that was left unanswered at the end of 4.1-why AOV and OAV constituent order are vanishingly rare (and do not appear in the corpus). The answer is that AOV and OAV constituent order require either (1) the co-occurrence of topicalization with focus or (2) the cooccurrence of either topic or focus with an indefinite argument, and both situations are quite unusual pragmatically.

6. Discussion. If we now return to England's criteria for BCO (given in 2.1), we find that they all converge on VOA constituent order as the BCO of Tenejapa Tzeltal and eliminate AVO from consideration. The three criteria that would eliminate AVO as a contender for the language's $\mathrm{BCO}$ are 5, 6 , and 7. Recall that criterion 5 holds that "sentences should not be ambiguous in interpretation of A and O"; criterion 6 holds that "no constituent is focused, topicalized, or otherwise highlighted"; and criterion 7 holds that "the subject noun is definite." I discuss each in turn.

Sentences with a preverbal NP (either AVO or OVA) fail criterion 5 because they are structurally ambiguous, owing to the fact that topicalization and focus are syntactically pivotless. Therefore, a focused constituent potentially corresponds to either A or $\mathrm{O}^{22}$ For example, (49) is potentially ambiguous between $\mathrm{A}$ and $\mathrm{O}$ focus, as illustrated in figure 2.

\footnotetext{
${ }^{22}$ The nature of pivot structure in topicalization is less straightforward. The only instances of the topicalization of $\mathrm{O}$ in the corpus are found in sentences where $\mathrm{A}>\mathrm{O}$ in animacy. There are no instances of topicalization when $\mathrm{A}=\mathrm{O}$ in animacy. This may have something to do with
} 


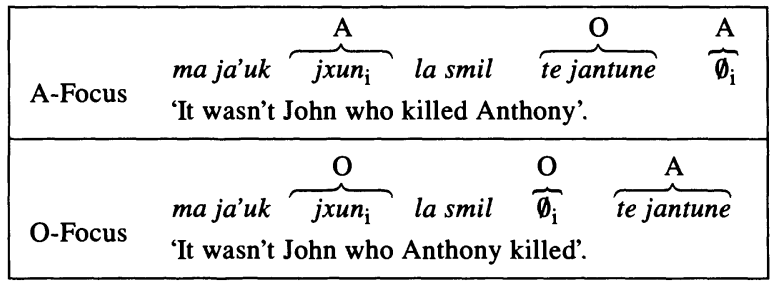

FIG. 2.-Ambiguity in narrow focus construction.

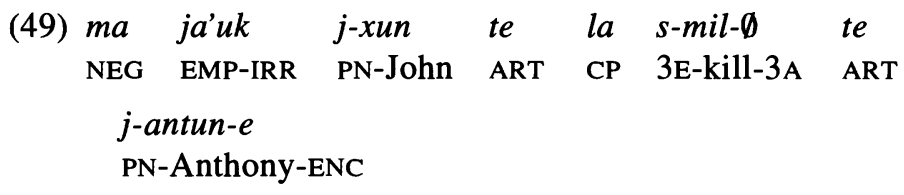

'It wasn't John who killed Anthony' or 'It wasn't John who Anthony killed'. [=(37)]

Criteria 6 and 7 are fairly straightforward and also argue against the basicness of AVO constituent order, which involves either topicalization or focus of A (in which case criterion 6 is not met) or an indefinite A (in which case criterion 7 is not met). There is an additional reason AVO is a poor contender for the BCO of Tenejapa Tzeltal: it is unclear whether topicalized NPs are even part of the constituent structure of transitive clauses. On the basis of her detailed analysis of Tzotzil, Jakaltek, and Tz'utujil, Aissen (1992) has argued for a distinction between internal and external topic positions. These two topic positions differ from one another in terms of their function and syntax. Although a detailed study of topics in Tzeltal remains to be done, two facts suggest that Tzeltal's topics are external topics. First, as noted in 5.1.2, topicalized arguments in Tenejapa Tzeltal cannot occur within complement clauses. Second, topics in Tenejapa Tzeltal are discourse topics (as opposed to "logical subjects" [Horn 1989, Kuroda 1992, and Ladusaw 1994]). It is possible, then, that Tenejapa Tzeltal's topics are external topics and therefore do not bear a necessary relationship to the

\footnotetext{
disambiguation. When $\mathrm{A}>\mathrm{O}$ in animacy, there is no confusion when $\mathrm{O}$ is topicalized (even though the sentence is structurally ambiguous), since real-world knowledge normally clarifies semantic roles. (For example, in 28, it is clear that it is the man who ties his shift around his belly and not the shirt that ties the man around its belly.) However, when $\mathrm{A}=\mathrm{O}$ in animacy, there is potential confusion concerning the assignment of semantic roles, and topicalization may therefore be barred for O's. This type of interaction between animacy and the possibilities for pragmatic highlighting has been reported for other Mayan languages. For example, Pinkerton (1976) reports that in K'ekchi it is not possible to have two preverbal NPs if $A=O$ in animacy. This is a question that merits further investigation.
} 
TABLE 8

Relative Frequency of BCO TyPes aCross LANGUAGes

\begin{tabular}{cccc}
\hline \hline & & Mallinson and \\
BCO Type & Ruhlen (1975) & Blake (1981) & Tomlin (1979) \\
\hline AOV & $52 \%$ & $41 \%$ & $45 \%$ \\
AVO & $36 \%$ & $35 \%$ & $42 \%$ \\
VAO & $11 \%$ & $9 \%$ & $9 \%$ \\
VOA & $2 \%$ & $2 \%$ & $3 \%$ \\
OVA & $0 \%$ & $1 \%$ & $1 \%$ \\
OAV & $0 \%$ & $1 \%$ & $0 \%$ \\
Unclassified & $0 \%$ & $11 \%$ & $0 \%$ \\
Total $n$ & 427 & 100 & 402 \\
\hline
\end{tabular}

argument structure of transitive clauses, although more work remains to be done before this assumption can be established.

These findings have a number of broader typological implications which should be made explicit. First, Tenejapa Tzeltal poses no significant problems for the concept of $\mathrm{BCO}$, although there are still lingering questions about some aspects of constituent order in the language-e.g., VAO constituent order (about which more shortly). All of the criteria for BCO converge on VOA for Tenejapa Tzeltal: frequency, lack of ambiguity, "pragmatic neutrality," etc. This does not mean that the concept is unproblematic or universally applicable (see Brody 1984 or Mithun 1992), but it does mean that for Tzeltal it is possible to postulate a single BCO.

Second, VOA languages (like Tenejapa Tzeltal) have been held up as counterevidence to the widely held "topic-first principle" (see, e.g., Firbas 1964, Greenberg 1966, Lyons 1977, or Givón 1979). This principle has been invoked to explain why various cross-linguistic surveys have shown that there is a strong tendency for A to precede $\mathrm{O}$ in languages with a BCO (Ruhlen 1975, Tomlin 1979, and Mallinson and Blake 1981), as shown in table 8. However, languages with VOA, OVA, or OAV as their BCO are well attested (see Pullum 1981a), which shows that the topic-first principle must be taken as a statistical generalization about language in general and not a universal claim that holds true for all languages. ${ }^{23}$

Nevertheless, the existence of an explicit clause-initial topic position in Tenejapa Tzeltal is consistent with Lambrecht's (1994:202) claim that "the topic-first principle can be maintained as a universal ordering principle, as long as it is only applied to accented lexical and pronominal topic expressions with a topic-announcing function." In other words, the topic-first

\footnotetext{
${ }^{23} \mathrm{~A}$ priori, we should not expect the topic-first principle to strongly constrain $\mathrm{BCO}$, since the identification of topic with subject is not complete in all languages ( $\mathrm{Li}$ and Thompson 1976).
} 
principle is tenable provided that the sort of topic to which it applies is a marked (or accented) topic expression, which is the case in Tenejapa Tzeltal, where there is an accented left-dislocated topic position that explicitly marks the constituent which occupies it as topic. ${ }^{24}$

Finally, I have found little evidence in favor of the claim, first made by Smith (1975) and later cited by Norman and Campbell (1978) and Dayley (1981), that Tenejapa Tzeltal constituent order is determined by a hierarchy of animacy (such that the constituent order is VAO when $A=O$ in animacy but VOA when $\mathrm{A}>\mathrm{O}$ in animacy). In fact, despite its size, the corpus contains only two potential instances of VAO constituent order: ${ }^{25}$

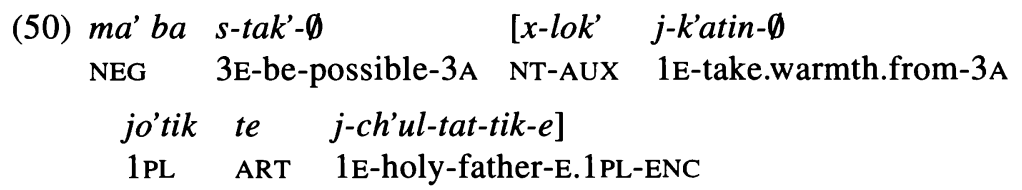

'It is not possible for us (excl.) to get out and warm ourselves in the sun'. (Stross 1977:22)
(51) tal laj y-ijkita-ik- $\emptyset$ jilel ta s-na s-me' AUX HS 3E-leave-PL-3A DIR P 3E-house 3E-mother $s$-tat te s-me'-ik te ala 3E-father ART 3E-mother-PL ART little j'ijk'al-etik-e blk.demon-PL-ENC

'The mothers $s_{i}$ of the little black demon boys came and left them at the houses of their ${ }_{i}$ parents'. [ $\left.=(15)\right]$

Neither instance supports the animacy-based account of Tenejapa Tzeltal's BCO. In (50), VAO constituent order results from the fact that the first-person plural exclusive is marked in Tenejapa Tzeltal by the use of first-person singular verb agreement with the first personal plural pronoun in a postverbal position. Since the first personal plural argument corresponds to A in this case, VAO constituent order results. However, when the first-person plural argument is O, VOA constituent order results. Both VAO and VOA constituent order for sentences with one first personal plural exclusive argument are illustrated in (52).

$\begin{array}{llllll}\text { (52a) } k \text {-ich'-oj- } \emptyset & \text { niwan } & \text { bel } & \text { jo'tik } & \text { jo'-winik } & \text { rosina } \\ \text { 1E-receive-STAT-3A } & \text { perhaps } & \text { DIR } & 1 \mathrm{PL} & \text { five-score } & \text { dozen }\end{array}$

\footnotetext{
${ }^{24}$ There may be other VOA languages which do not support Lambrecht's claim-e.g., Ojibwa (Tomlin and Russell 1979).

${ }^{25}$ (50) was not counted in the analysis of transitive clauses with two lexical core arguments since it is a complex sentence and has a first-person core argument (see 3.2).
} 
$\begin{array}{llll}a & \text { te } & \text { karchucha nichim-e } \\ \text { DEM } & \text { ART } & \text { cartucha } & \text { flower-ENC }\end{array}$

'We had brought perhaps one-hundred dozen cartucha flowers'.

(52b) jich ta ora la s-man-be-n jo'tik j-cha'

thus $P$ now CP 3E-buy-BEN-1A.SG 1PL 1-NC

chonolajel

merchant

'Right away a merchant bought it from us'. (Méndez Guzmán 1996:32)

The sentence in (51) is somewhat puzzling and difficult to interpret, for a number of reasons. First, the meaning of the sentence in the context of the story is debatable and the translation given here differs from that of Stross (1978:3). Second, it seems to involve coreference between $O$ and the possessor of $\mathrm{A}$, which is normally not possible in the language-see Aissen (1997) for an account of similar constraints in Tzotzil in terms of obviation. Future work should investigate the nature of coreferential omission within sentences as well as other factors which might license departures from Tenejapa Tzeltal's BCO-e.g., constituent "heaviness," which seems relevant to constituent ordering, judging from examples like (53), where A occurs immediately after the matrix verb and before the complement clause.

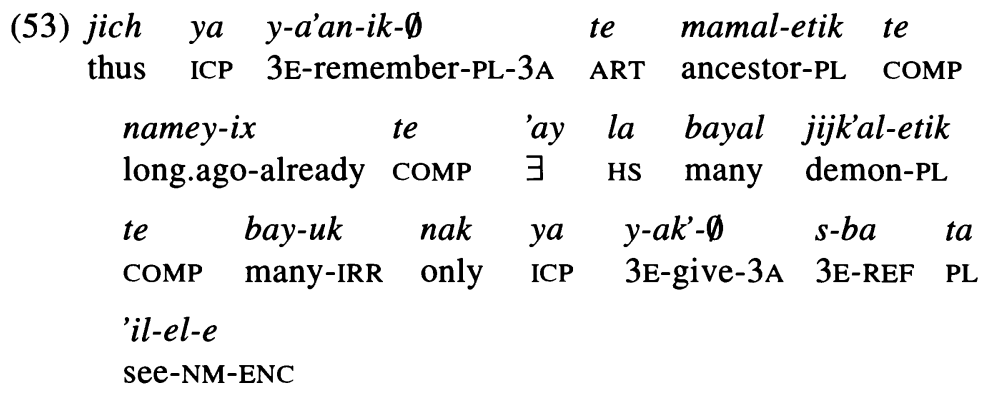

'The ancestors remember that long ago there was a countless number of black demons that could be seen anywhere'. (Pérez and Gómez 1986:40)

7. Conclusion. In summary, I have examined a corpus of Tenejapa Tzeltal narrative texts for statistical patterns in constituent ordering and elision and found that the majority of transitive clauses possess one or more elided core arguments and that clauses with two full lexical arguments are relatively infrequent. VO constituent order was found to be predominant in clauses with a single lexical core argument, while VOA constituent order 
was predominant in clauses with two lexical core arguments. On the basis of these statistical findings, combined with more careful structural analysis, I have claimed that the basic constituent order of Tzeltal is VOA and that departures from this order can be explained by the nature of information structures in Tenejapa Tzeltal, which associates topicalized, focused, and indefinite arguments with preverbal argument positions. Previous claims for an animacy-based account of Tenejapa Tzeltal's constituent order are not supported by my data.

\section{REFERENCES}

Aissen, Judith. 1987. Tzotzil Clause Structure. Amsterdam: D. Reidel.

1992. Topic and focus in Mayan. Language 68:43-80.

1997. On the syntax of obviation. Language 73:705-50.

1999. External possessor and logical subject in Tz'utujil. External Possession, ed.

Doris Payne and Immanuel Barshi, pp. 167-93. Amsterdam: John Benjamins.

ANDREws, Avery. 1985. The major functions of the NP. Language Typology and Syntactic

Description, ed. Tim Shopen, pp. 62-154. Cambridge: Cambridge University Press.

Berlin, Brent. 1968. Tzeltal Numeral Classifiers: A Study in Ethnographic Semantics. The Hague: Mouton de Gruyter.

BRODY, JiLL. 1984. Some problems with the concept of basic word order. Linguistics 22:711-36.

BRown, PENELOPE. 1998. Children's first verbs in Tzeltal: evidence for an early verb category. Linguistics 36:713-53.

Brown, Penelope, and Stephen C. Levinson. 1993. "Uphill” and "downhill” in Tzeltal. Journal of Linguistic Anthropology 3:46-74.

2000. Frames of spatial reference and their acquisition in Tenejapan Tzeltal. Culture, Thought, and Development, ed. Larry Nucci, Geoffrey Saxe, and Elliot Turiel, pp. 167-97. Mahwah, N.J.: Erlbaum.

CAMPBell, Lyle. 1987. Tzeltal dialects: new and old. Anthropological Linguistics 29:549-70.

Campbell, Lyle, and TerRence Kaufman. 1985. Maya linguistics: where are we now? Annual Review of Anthropology 14:187-98.

Chafe, Wallace. 1987. Cognitive constraints on information flow. Coherence and Grounding in Discourse, ed. Russell Tomlin, pp. 21-52. Amsterdam: John Benjamins.

CHOMSKY, NoAm. 1957. Syntactic Structures. The Hague: Mouton.

ComRIE, BeRnARD. 1989. Language Universals and Linguistic Typology. Chicago: University of Chicago Press.

DAYLEY, Jon P. 1981. Voice and ergativity in Mayan languages. Journal of Mayan Linguistics 2:3-82.

Dixon, R. M. W. 1979. Ergativity. Language 55:59-138. 1994. Ergativity. Cambridge: Cambridge University Press.

DRYER, MATTHEW S. 1995. Frequency and pragmatically unmarked word order. Word Order in Discourse, ed. Pamela Downing and Michael Noonan, pp. 105-35. Amsterdam: John Benjamins.

DuBors, JoHN. 1987. The discourse basis of ergativity. Language 63:805-55.

ENGLAND, NORA C. 1991. Changes in basic word order in Mayan languages. IJAL 57:446-86.

FIRBAS, JAN. 1964. On defining the theme in functional sentence analysis. Travaux Linguistiques de Prague 1:267-80. 
Foley, William A., ANd Robert D. VAN VAlin, JR. 1984. Functional Syntax and Universal Grammar. Cambridge: Cambridge University Press.

FriedL, JefFrey E. F. 1997. Mastering Regular Expressions: Powerful Techniques for Perl and Other Tools. Cambridge: O'Reilly.

FRISHBERG, NANCY. 1972. Navaho object markers and the great chain of being. Syntax and Semantics, vol. 1, ed. John P. Kimball, pp. 259-66. New York: Seminar Press.

Givón, TALMY. 1979. On Understanding Grammar. New York: Academic Press.

GREENBERG, JosEPH H. 1966. Some universals of grammar with particular reference to the order of meaningful elements. Universals of Grammar, 2d ed., ed. Joseph H. Greenberg, pp. 73-113. Cambridge, Mass.: The M.I.T. Press.

Griswold, Ralph E., AND MAdGe T. Griswold. 1997. The Icon Programming Language. 3d ed. San Jose, Calif.: Peer-to-Peer Communications.

Haviland, John B. 1981. Sk'op Sotz’leb: el Tzotzil de Zinacantán. Mexico City: UNAM Press.

Hawkins, John A. 1983. Word Order Universals. New York: Academic Press.

HOPPER, PAUL J. 1987. Emergent grammar. Proceedings of the Thirteenth Annual Meeting of the Berkeley Linguistics Society, ed. Jon Aske et al., pp. 139-57. Berkeley: University of California.

Hopper, Paul J., AND SANDra A. Thompson. 1980. Transitivity in grammar and discourse. Language 56:251-99.

Horn, LaURence. 1989. A Natural History of Negation. Chicago: University of Chicago Press.

Hunn, Eugene. 1977. Tzeltal Folk Zoology: The Classification of Discontinuities in Nature. New York: Academic Press.

Kaufman, Terrence. 1971. Tzeltal Phonology and Morphology. Berkeley and Los Angeles: University of California Press.

Kuroda, S.-Y. 1992. Japanese Syntax and Semantics. Dordrecht: Kluwer.

LADUSAW, William. 1994. Thetic and categorical, state and individual, weak and strong. Proceedings of the Conference on Semantics and Linguistic Theory 4, pp. 220-29. Ithaca, N.Y.: Department of Modern Languages and Linguistics, Cornell University.

LAMBRECHT, KNUD. 1986. Topic, focus, and the grammar of spoken French. Ph.D. dissertation, University of California, Berkeley.

1994. Information Structure and Sentence Form: Topic, Focus and the Mental Representation of Discourse Referents. Cambridge: Cambridge University Press.

Laughlin, Robert M. 1977. Of Cabbages and Kings: Tales from Zinacantán. Washington, D.C.: Smithsonian Institution Press.

Li, Charles N., and Sandra A. Thompson. 1976. Subject and topic: a new typology of language. Subject and Topic, ed. Charles N. Li, pp. 457-89. New York: Academic Press.

Lyons, John. 1977. Semantics. Cambridge: Cambridge University Press.

Mallinson, Graham, And Barry J. Blake. 1981. Language Typology. Amsterdam: NorthHolland.

Méndez Guzmán, Diego. 1996. A'yejetik yu'un Jtzeltaletik ta Tenejapa/Relatos Tzeltales de Tenejapa. México: Instituto Nacional Indígenista.

Méndez López, Alonzo, and Diego Méndez Guzmán. 1992. Sk'oplal Kajkanantik (La Leyenda de San Idelfonso), trans. Jose Alfredo Melo de la Rosa Francisco Alvarez Q. San Cristóbal de las Casas, Chiapas: Sna Jtz'ibajom, Cultura de los Indios Mayas, A.C.

Mithun, Marianne. 1992. Is basic word order universal? Pragmatics of Word Order Flexibility, ed. Doris L. Payne, pp. 15-61. Amsterdam: John Benjamins.

Norman, William M., and Lyle Campbell. 1978. Toward a Proto-Mayan syntax: a comparative perspective on grammar. Papers in Mayan Linguistics, ed. Nora C. England, 
University of Missouri Miscellaneous Publications in Anthropology 6 and Studies in Mayan Linguistics 2. Columbia: University of Missouri.

Pérez López, EnRiQue, and Martin Gómez Ramírez. 1986. Relatos y tradición de un pueblo tzeltal: K'op a'yejetik sok xkuxinel te muk'ul lum tzeltal. Chiapas: Fortalecimiento y fomento a las culturas de la sub-secretaria de asuntos indígenas.

Pinkerton, SandRa. 1976. Ergativity and word order. Studies in K'ekchi, ed. Sandra Pinkerton, pp. 44-66. Austin: University of Texas.

Prince, Ellen. 1981. Toward a taxonomy of given-new information. Radical Pragmatics, ed. Peter Cole, pp. 223-55. New York: Academic Press.

Pullum, Geoffrey. 1977. Word order universals and grammatical relations. Grammatical Relations, ed. Peter Cole and Jerrold Saddock, pp. 249-77. New York: Academic Press. . 1981a. Languages with object before subject: a comment and a catalogue. Linguistics 19:147-55. . 1981b. Object-initial languages. IJAL 47:192-214.

Ramírez Hernández, Sebastían. 1994. El Negro. Relatos Tzeltales y Tzotziles: Lo'il Maxiel, pp. 129-35. Mexico City: Editorial Diana.

Robinson, Stuart P. 1996. The -van antipassive in Tzotzil: a discourse perspective. B.A. thesis, Reed College.

Robles Uribe, Carlos. 1962. Manual del Tzeltal (Gramática Tzeltal de Bachajón). México: Universidad Iberoamericana.

RuHLen, M. 1975. A Guide to the Languages of the World. Stanford, Calif.: Language Universals Project, Stanford University.

Smith, Joshua Hinmán. 1975. La familia tzeltana. Paper presented at the Mayan Workshop, Antigua, Guatemala, August 1975.

Stross, Brian. 1973. Acquisition of botanical terminology by Tzeltal children. Meaning in Mayan Languages, ed. Munro S. Edmonson, pp. 107-41. The Hague: Mouton de Gruyter. 1977. Love in the Armpit: Tzeltal Tales of Love, Murder and Cannibalism. Museum Brief 23. Columbia: Museum of Anthropology of Missouri.

1978. Tzeltal Tales of Demons and Monsters. Museum Brief 24. Columbia: Museum of Anthropology of Missouri.

1979. Tzeltal texts. Mayan Texts II, IJAL Native American Texts Series, vol. 3, ed. Louanna Furbee-Losee, pp. 106-21. Chicago: University of Chicago Press.

Tomlin, Russell. 1979. An explanation of the distribution of basic constituent orders. Ph.D. dissertation, University of Michigan.

1986. Basic Word Order: Functional Principles. London: Croom Helm.

TOMLIN, RusSELl, AND RICHARD RHODES. 1979. An introduction to information distribution in Ojibwa. Papers from the Fifteenth Regional Meeting of the Chicago Linguistic Society, ed. P. Clyne et al., pp. 307-21. Chicago: Chicago Linguistic Society. 